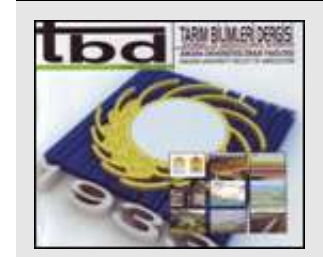

Tarım Bilimleri Dergisi Tar. Bil. Der.

Dergi web sayfasi: www.agri.ankara.edu.tr/dergi
Journal of Agricultural Sciences

Journal homepage:

www.agri.ankara.edu.tr/journal

\title{
Domestic Tractor Market Share Estimation by Time Series Analysis Method
}

\author{
Burcu HAMLECía ${ }^{\mathrm{a}}$, Metin GÜNER ${ }^{\mathrm{b}}$

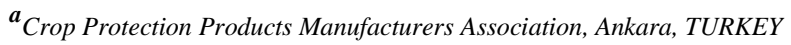

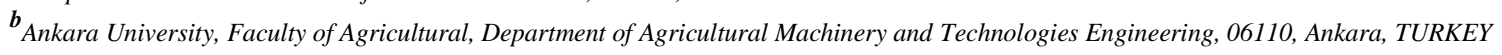

\author{
ARTICLE INFO \\ Research Article \\ Corresponding Author: Metin GÜNER, E-mail: metguner@gmail.com, Tel: +90 (553) 6984406 \\ Received: 14 December 2018, Received in Revised Form: 05 July 2019, Accepted: 25 July 2019
}

\section{AUTHORS ORCID ID:}

(Burcu HAMLECİ: 0000-0002-6383-5211), (Metin GÜNER: 0000-0002-5681-1625)

\begin{abstract}
This study is aimed to examine the domestic tractor market share with time series analysis to forecast the future probabilities with the help of the models which are created according to the Box-Jenkins method. The study was planned for year 2010, based on 5 different
\end{abstract}

Keywords: Box-Jenkins; Tractor market share estimation; Time series analysis; Forecast

(C) Ankara Üniversitesi Ziraat Fakültesi

\section{Introduction}

Predicting the future is an indispensable element of a socio-economic development. It is possible for private or public organizations to maintain or improve their future status only if they are able to predict events and find appropriate solutions with good planning. One of the methods used to predict the future is the time series. A time series consists of observation values sorted by time for any variable. Time series analysis is used to create a forecast model for the future periods using the previous period data of the variable to be predicted. Analysis of the time series of the model variable related to the model development is based on determining the main trend and its characteristics. It is used in the estimation phase considering that the model, whose accuracy is accepted under various constraints, will show the same tendency and similar characteristics in the future periods. Predicting the future is an indispensable element of a socio-economic development. It is possible for private or public organizations to maintain or improve their future status only if they are able to predict events and find appropriate solutions with good planning. The benefits of predicting the future can be given as 1 . Help the company predict the future, 2 . Responds to customers' needs, 3 . No reduce your sales, 4 . Reduces stocking costs, 5. Capture opportunities, 6. Allows you to plan cash flow, 7. It allows us to give the right and timely reproduction decisions, 8. Helps you to make your premium planning fair, 9. Improves your business processes.

Alon \& Sadowski (2001) used the Box-Jenkins method in the time series analysis of US integrated retail sales. Burger et al (2001) used time series analysis and done a work on the estimation of travel demands of the tourists. Zhou et al (2002) used the time series analysis method to estimate hourly and daily water demand. Chu \& Zhang (2003), using the monthly retail sales data for the years 1985-1999 from the US population administration, conducted studies on the estimation of sales with linear and non-linear models. Yeşil (2007) examined how demand forecasts, which are required 
as input of the process, are affected by the use of traditional and current estimation methods when using the production planning model in stock. As a result of the results obtained, the sector and the most effective forecasting model for the selected sample were evaluated. The time series analysis technique indicated that the estimation values that best represent the actual sales data were achieved. Bek (2008) examined the basic concepts used in time series analysis and ARMA, ARIMA, seasonal Box-Jenkins models and seasonal autoregressive models SAR (P). In order to make the best model choice, it has examined different models. ARIMA $(0,1,7)(1,0,1)$ model was proposed as the best model. Berberoğlu (2010) used time series methods to model milk yields. It is concluded that ARIMA model models the milk yield better and predicts the actual values. Karaman (2010) aimed to determine the control day milk yields by time series method and to determine the number of control days providing the most accurate estimates. The researcher, with the results he obtained, argued that time series approach could be useful in predicting milk yield. In his study, Oğhan (2010) applied Holt Exponential Straightening and Box-Jenkins methods to one of the univariate time series analysis methods for cow's milk prices and made estimates for the series. The researcher stated that time series analyzes were guiding the decision maker in order to direct the producers and determine the policies. Özek (2010) examined the graphs used to determine an initial model for a time series. The researcher stated that ACF and PACF graphs are very useful in determining a suitable model for linear time series. Öztaş (2012) argued that time series are one of the most suitable methods in their short term estimations. Celik (2013) analyzed the time series of traffic accidents in Turkey and determining the most suitable time series model aimed to estimate of the number of accidents in the future. Özer \& İlkdoğan (2013) examined the cotton prices in the world with the ARIMA model, the Box-Jenkins method. Ali (2015) aimed to estimate unemployment and inflation and to determine the relationship between unemployment and inflation. The 5-year data of PM10 air pollutant from air quality measurement station were investigated by Turgut \& Temiz (2015). Kapucuoğlu (2016) used analytic network process (ANP) to predict the Turkey tractor market share. In the comparison with the actual market shares of the tractor companies, which are estimated to be "new" and "second hand", it is observed that the estimated values are quite close to the real values on the basis of sector leadership. However, it is necessary not to ignore the sector conditions of the relevant years in the studies to be done.

According to the above researches, time series analysis and modeling has many business and social applications. It is extensively used to forecast company sales, product demand, stock market trends, and agricultural production. BoxJenkins method is a superior method in determining the structure of a time series, observing the most effective use of observations between them and providing statistical tests in the model determination stages. People face problems of decision making in everyday life. Although some decisions are very simple; many require analysis because of the interactions between factors that influence the decision. Time series method is to make future estimations based on observation of the past. The observation of the past can be done by means of statistical data, in other words, with time series. The tendency is determined by using time series and the consumption of goods and services foreseen in production in previous years. And predictions are made on the assumption that future demand will develop in the same way. Agricultural machinery marketers, producers, tractor companies and all other sales companies want to know how much they will sell in the future.

The aim of this study is to estimate the local tractor market share by means of Time Series Analysis which is one of the quantitative (numerical) estimation techniques. This study is aimed to investigate the local market share of the local tractor by time series analysis and to make future estimations with the help of the models which are formed according to the Box-Jenkins method. The market share of the five local firms which have the largest share in Turkey's tractor market is estimated. In this study, tractor sales values of 5 tractor companies are tried to be estimated, not tractor production. In addition, the total number of tractors including all tractor brands is estimated and the usability of time series method has been investigated in the determination of tractor sales values of tractor companies in the future.

\section{Material and Methods}

\subsection{Material}

In this study, we used the monthly sales value data of 5 domestic tractor companies between the years 2005 and 2009 . In order to expand the study, the total tractor numbers of all tractor brands were also included between the years 1991-2009. The number of tractor numbers is the sales values of 5 tractor companies included their own manufactured tractors as well as the ones which were purchased from abroad. Box-Jenkins method was used to analyze the time series methods. The data were further analyzed using SPSS 20 statistical package program. Table 1 gives information about five tractor companies. Company names are named as A, B, C, D, and E. 
Table 1- Introductory information of five tractor companies

\begin{tabular}{|c|c|c|c|c|c|}
\hline Power range (HP) & $35-120$ & $50-113$ & $48-400$ & $48-380$ & $50-115$ \\
\hline Gear option (units) & 4 & 7 & 4 & 13 & 6 \\
\hline Case type (rops, sun visor, cabin) & 3 & 3 & 2 & 3 & 2 \\
\hline Number of sellers (units) & 53 & 143 & 63 & 103 & 94 \\
\hline Color option (pcs) & 1 & 1 & 6 & 1 & 1 \\
\hline
\end{tabular}

\subsection{Methods}

Sales numbers of 2010 were estimated by using the time series analysis method and SPSS statistical package program by using the tractor sales units of the period 2005-2009 for 5 different tractor brands. A similar study was conducted for the total number of tractors belonging to the period of 1991-2009. The total number of tractors estimated by time series analysis was obtained and these estimation values were compared with the actual total tractor numbers. Box-Jenkins method was used in the research. Box-Jenkins method, also known as ARIMA modeling approach; is a statistical method used for predicting single variable time series. The Box-Jenkins method has three models. These are the autoregressive process, the moving average (MA) and the moving autoregressive (ARMA) processes. The ARMA process becomes an integrated motion autoregressive (ARIMA) process when a difference is required for a non-stationary series. The following steps are followed to determine the model with the Box-Jenkins method. 1. Graphs of time (graphs of time series) of the observations are plotted. 2. Data are analyzed and the stability requirement is sought by looking at the ACF (autocorrelation values) and PACF (partial autocorrelation values) graphs. 3. Stability is obtained by taking sufficient difference in non-stationary data. 4. Unit root test is performed and ACF and PACF graphs are checked to see if stability is achieved. 5. After the series has stabilized and truncated, the period of the series is determined by looking at the obtained autocorrelation values. 6. After the period is determined, ACF and PACF graphs are taken into consideration to decide the model (for the determination of AR and MA model ranges). According to the information obtained from these graphs, the degrees of AR and MA models are entered into SPSS program and multiple models are created separately. 7. The meaningful ones are selected from these models created by the help of SPSS program and the meaningless ones are eliminated. 8. The model with the lowest BIC (Schwartz Bayesian information criterion) value is chosen as the most suitable model among the sig <0.05 models. 9. Estimates are made when the condition of the model is sufficient. 10. In the last step, ACF and PACF graphs of errors are generated to see if any errors in the model are white noise. If the errors are white noise, the estimation is determined to be reliable.

\section{Results and Discussion}

\subsection{Findings related to time series methods of tractor sales and model estimation}

Sales figures of A, B, C, D and E tractor brands were plotted. Declines and increases in the graphs were observed. Declines and increases in the graphs show that there is a trend, meaning that the series is non-stationary. It is necessary to look at the ACF (autocorrelation values) and PACF (partial autocorrelation values) graphs of the data and also the unit root test (ADF) results to see that there is a trend (Figures 1,2,3,4, and 5). 


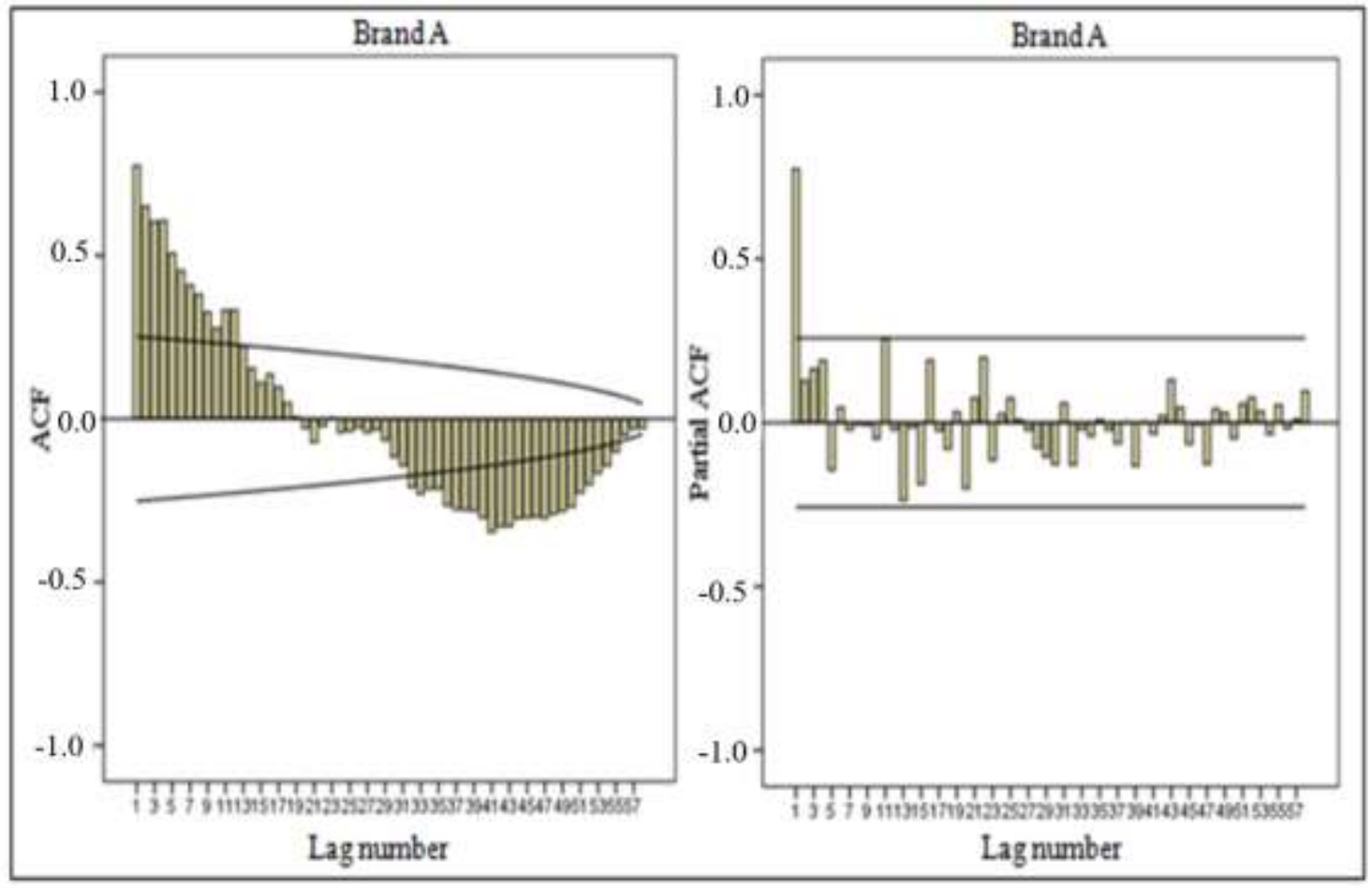

Figure 1- ACF and PACF graphs of brand A

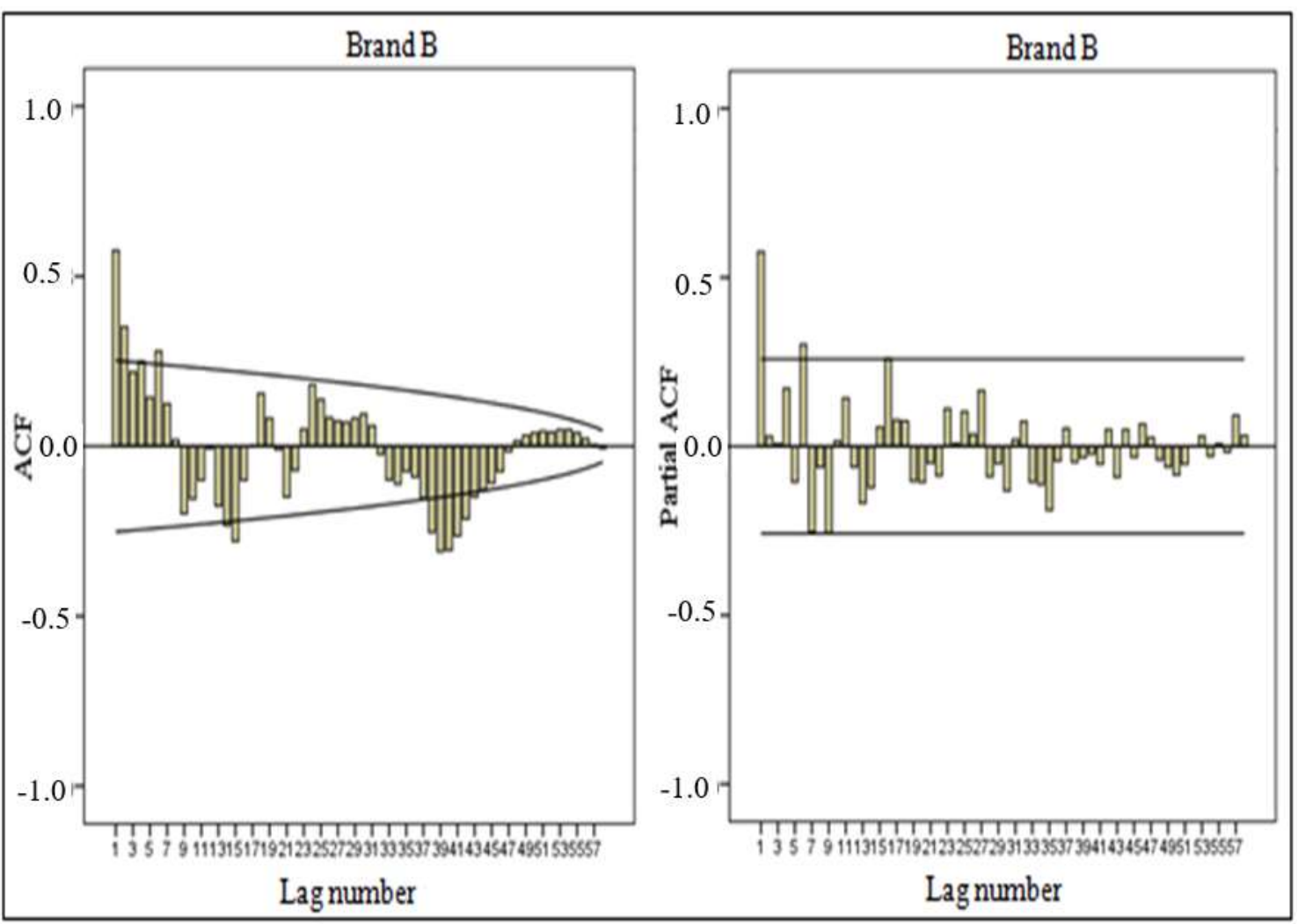

Figure 2- ACF and PACF graphs of brand B 


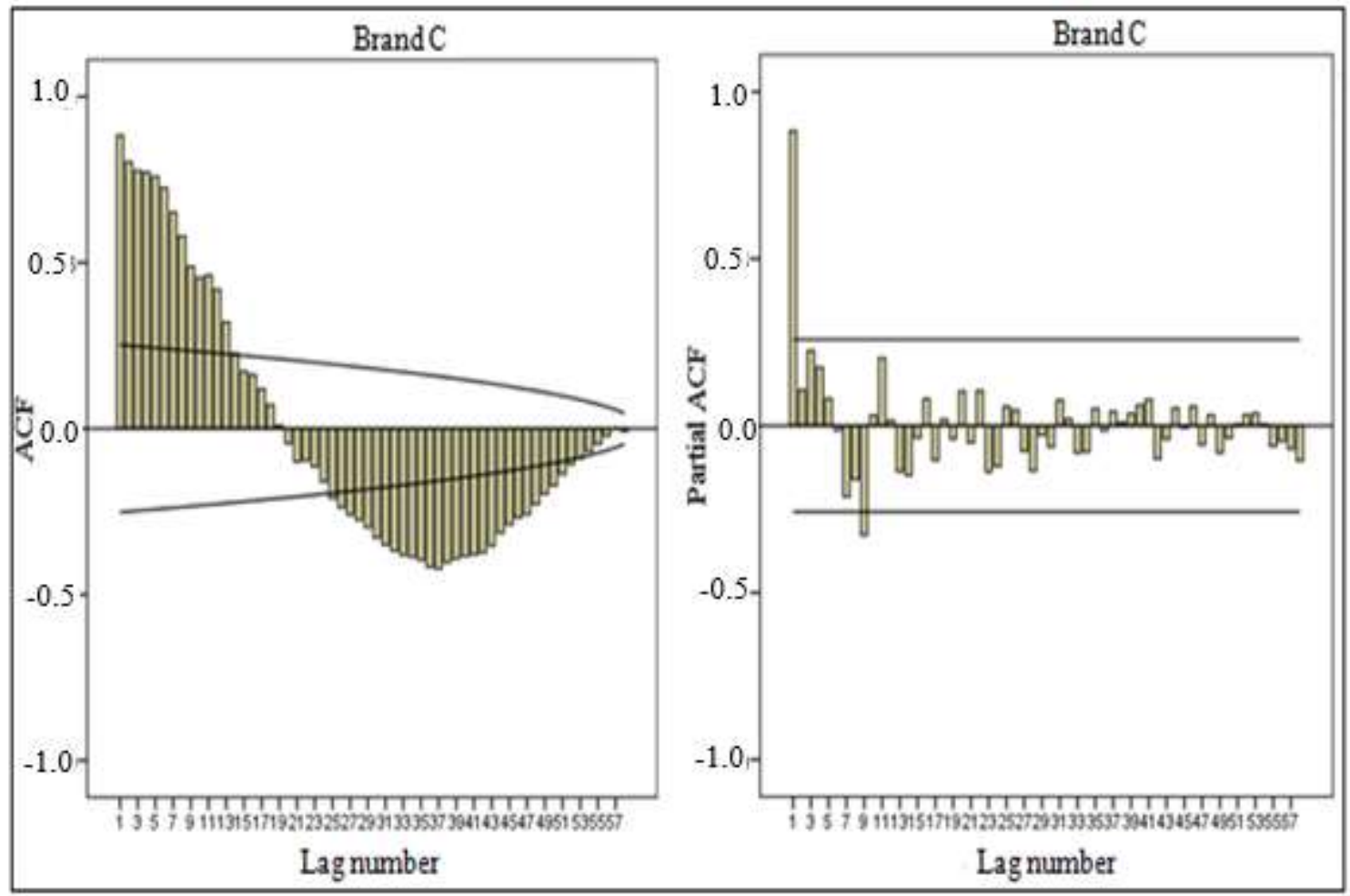

Figure 3- ACF and PACF graphs of brand C

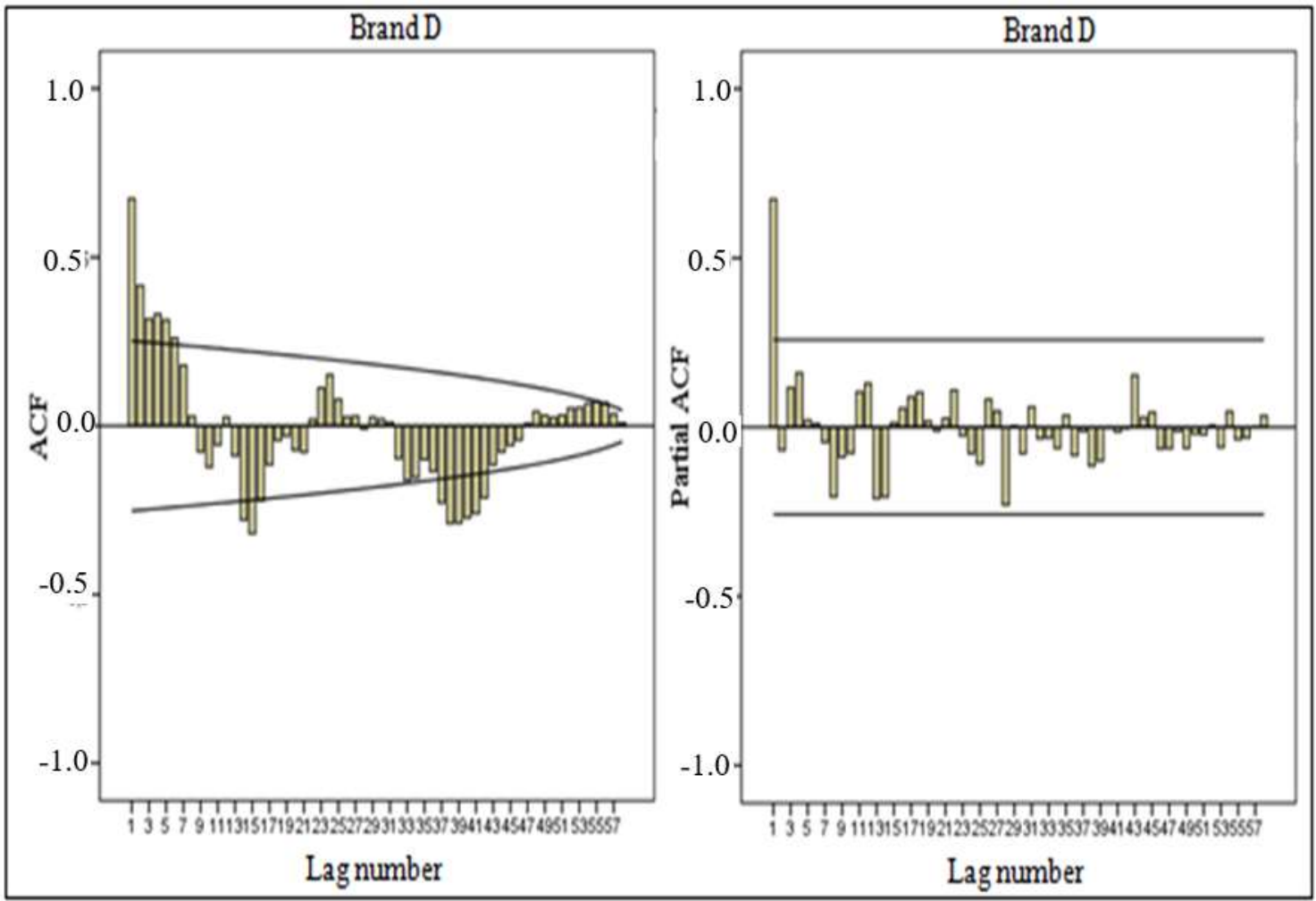

Figure 4- ACF and PACF graphs of the D brand 


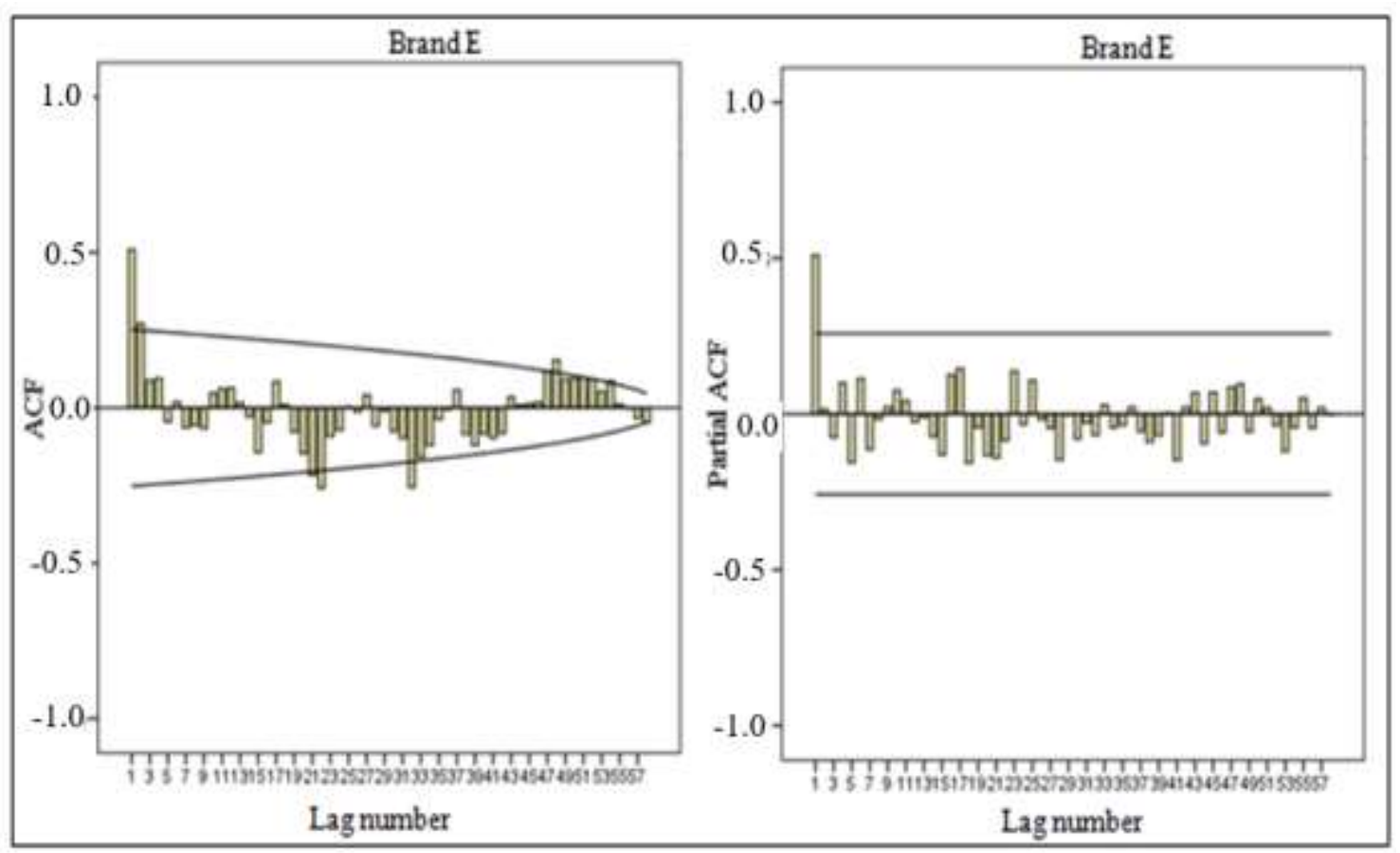

Figure 5- ACF and PACF graphs of the E brand

It was found that for brands A, B, C and D, there are trends in the data since many delays exceed the confidence limits; it can be said that the series is non-stationary. In order to continue the analysis, the data should be truncated. In order to ensure the stability of the series, the first order difference was performed by using SPSS package program. For the E brand, it is understood that there is no trend in the series, ie the series is stationary. When we look at the difference between the A, B, C and D brands, the ACF and PACF graphs show that the delays are within the confidence limits. Therefore, it can be said that the data is free from the trend (Figures 6, 7, 8, and 9).

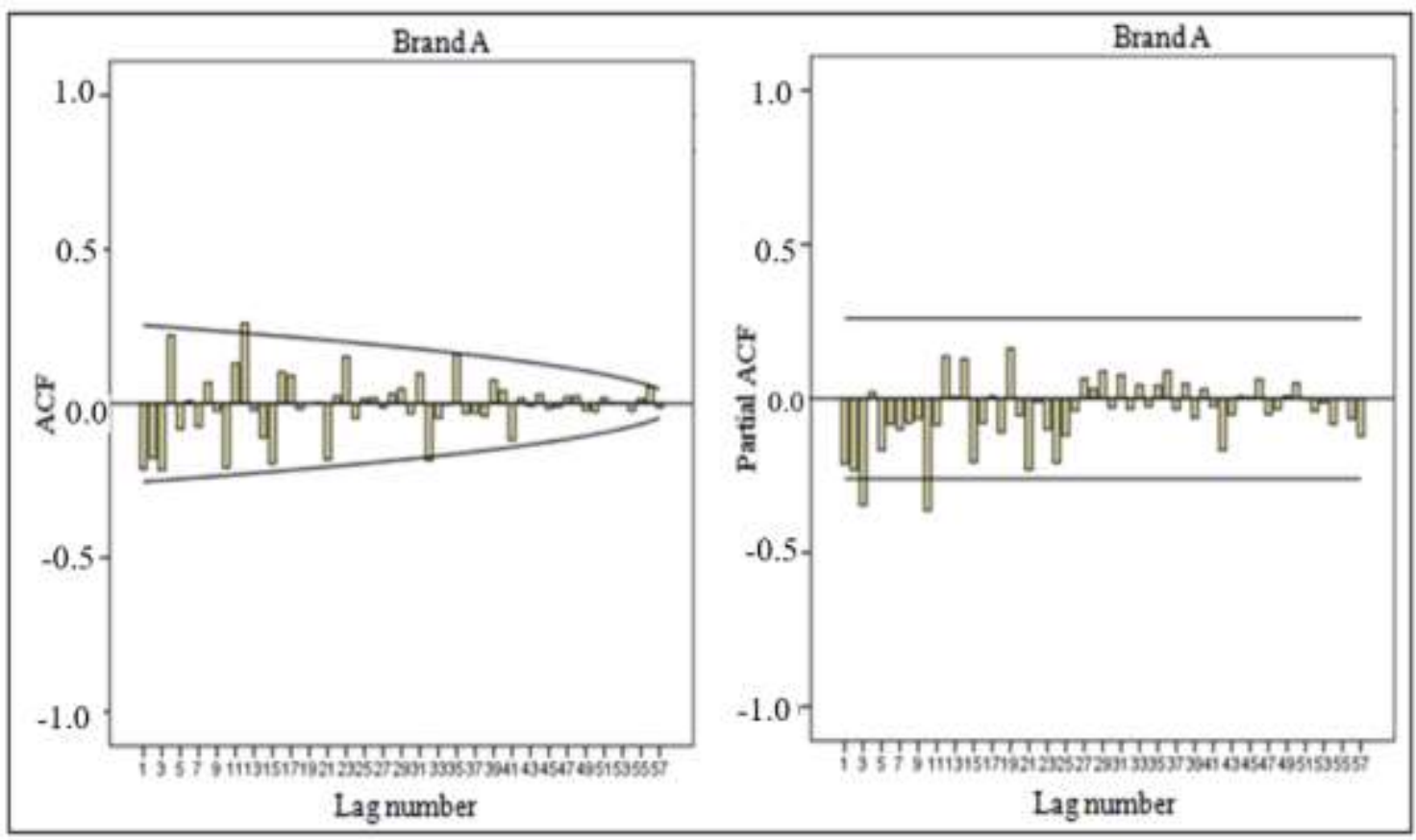

Figure 6- Difference-treated ACF and PACF graphs of brand A 


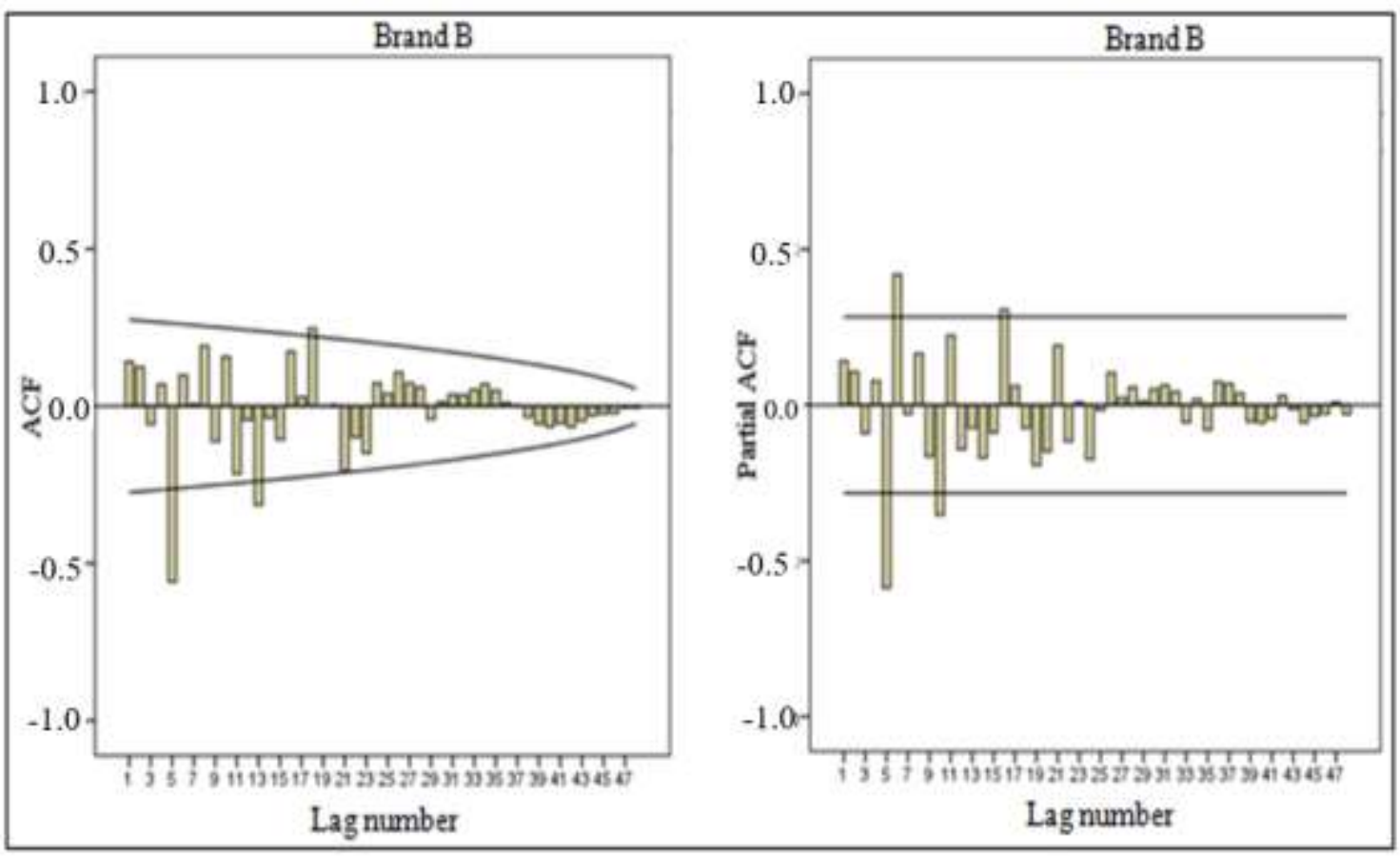

Figure 7- Difference-treated ACF and PACF graphs of brand B

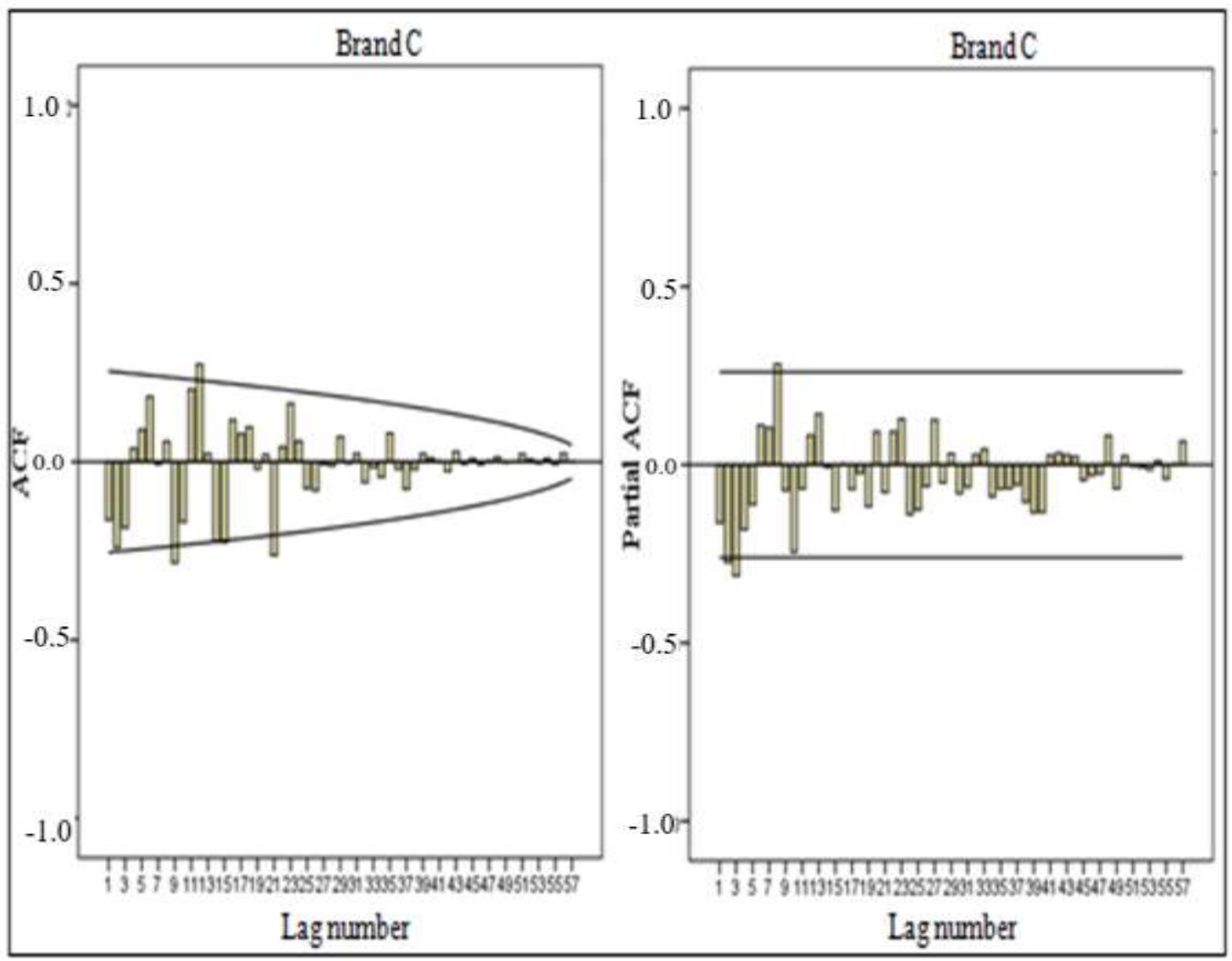

Figure 8- Difference-treated ACF and PACF graphs of brand C 


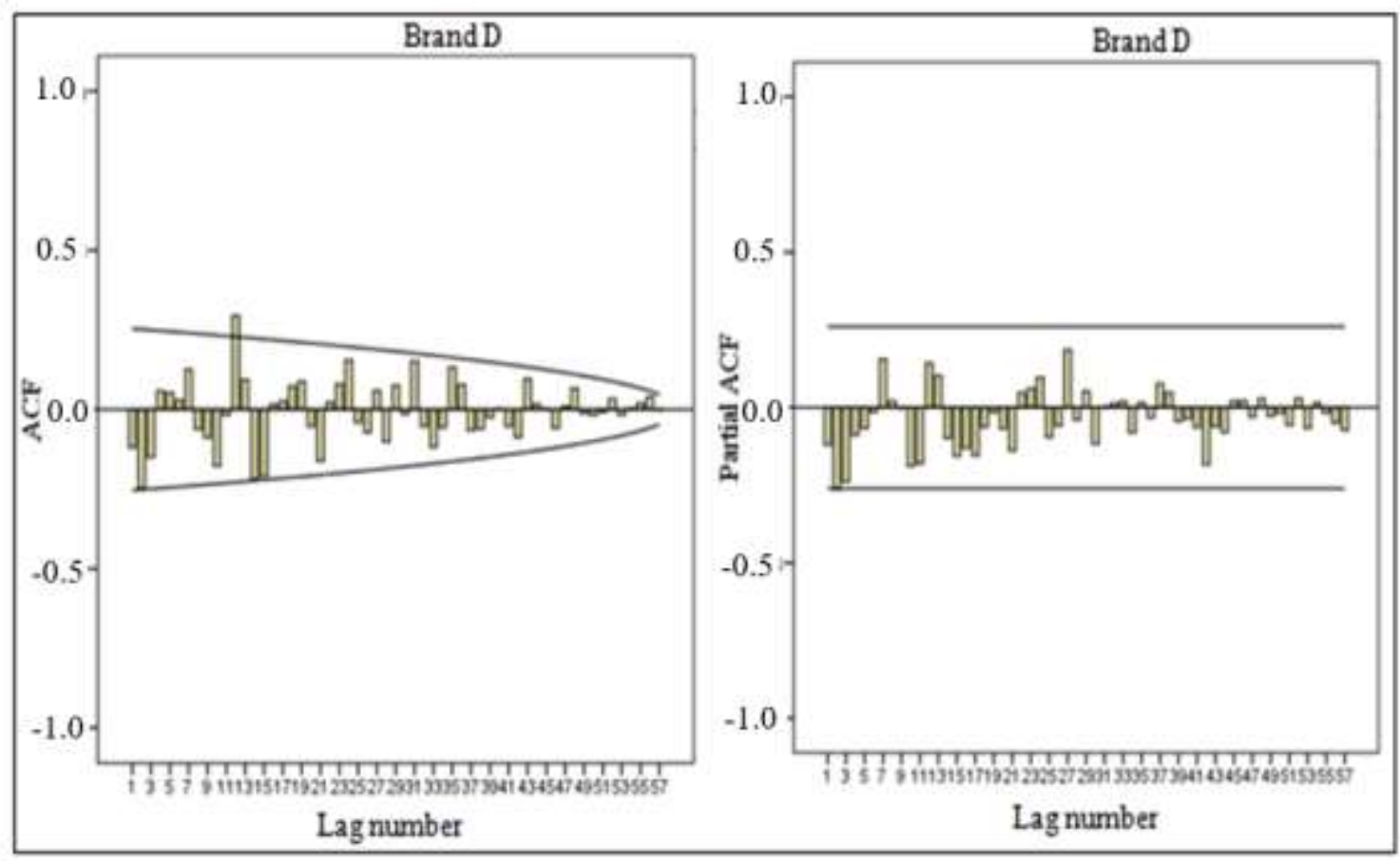

Figure 9- Difference-treated ACF and PACF graphs of brand D

The ADF test (Unit Root Test) was applied to determine whether the difference was stable or not (Berberoğlu 2010). In other words, it has been investigated by the extended Dickey Fuller (ADF) test whether the change in the number of tractor sales has a unit root. According to the results of Unit Root Test obtained in Tables 2, the ADF test statistic is greater than the critical value. From these results, it is concluded that the series is free of trend; in other words, it is understood that the series is not rooted in the unit. Also, the probability value $(\mathrm{P})$ is less than $0.05(\mathrm{P}<0.05)$ and the series is stationary. Therefore, the series has been successfully transformed into a stable state with first order difference.

Table 2- Unit Root Test for brands A, B,C,D,E (ADF tests)

\begin{tabular}{|c|c|c|c|c|}
\hline \multicolumn{5}{|c|}{ Augmented Dickey-Fuller Unit Root Test on $D(A, B, C, D, E)$} \\
\hline \multirow{3}{*}{\multicolumn{5}{|c|}{$\begin{array}{l}\text { Null Hypothesis:D (A, B,C,D,E ) has a unit root } \\
\text { Exogenous: Constant } \\
\text { Lag Length: 0-4-2-0-0 (Automatic - based on SIC, maxlag=10) }\end{array}$}} \\
\hline & & & & \\
\hline & & & & \\
\hline & & Tractor Brands & t-statistics & $P$-probability \\
\hline \multirow{5}{*}{\multicolumn{2}{|c|}{ Augmented Dickey-Fuller Test Statistic }} & A & -9.474 & $<0.001$ \\
\hline & & $\mathrm{B}$ & -5.760 & $<0.001$ \\
\hline & & $\mathrm{C}$ & -7.504 & $<0.001$ \\
\hline & & $\mathrm{D}$ & -8.451 & $<0.001$ \\
\hline & & $\mathrm{E}$ & -4.061 & 0.002 \\
\hline \multirow{15}{*}{ Critical values } & \multirow{5}{*}{$1 \%$ level } & A & -3.548 & $<0.001$ \\
\hline & & $\mathrm{B}$ & -3.557 & $<0.001$ \\
\hline & & $\mathrm{C}$ & -3.552 & $<0.001$ \\
\hline & & $\mathrm{D}$ & -3.548 & $<0.001$ \\
\hline & & $\mathrm{E}$ & -3.546 & 0.002 \\
\hline & \multirow{5}{*}{$5 \%$ level } & $\mathrm{A}$ & -2.912 & $<0.001$ \\
\hline & & B & -2.916 & $<0.001$ \\
\hline & & $\mathrm{C}$ & -2.914 & $<0.001$ \\
\hline & & D & -2.912 & $<0.001$ \\
\hline & & $\mathrm{E}$ & -2.911 & 0.002 \\
\hline & \multirow{5}{*}{$10 \%$ level } & $\mathrm{A}$ & -2.594 & $<0.001$ \\
\hline & & B & -2.596 & $<0.001$ \\
\hline & & $\mathrm{C}$ & -2.595 & $<0.001$ \\
\hline & & D & -2.594 & $<0.001$ \\
\hline & & $\mathrm{E}$ & -2.593 & 0.002 \\
\hline
\end{tabular}


Table 3, 4, 5,6 and 7 shows the ARIMA model parameters for the brand A-B-C-D-E. The degrees of AR and MA models obtained from the ACF and PACF graphs are entered into the statistic program (SPSS). And then, the model parameters are obtained with BIC values. According to the test results, Ho (absence hypothesis) is rejected because ( $\operatorname{sig}<0.001)<(\alpha$ $=0.05$ ). Therefore, it can be said that the decision model is meaningful.

Table 3- ARIMA model parameters for brand A

\begin{tabular}{|c|c|c|c|c|c|c|c|}
\hline Brand & & & & Estimate & $S E$ & $t$ & Sig. \\
\hline \multirow{4}{*}{ A-brand_1 } & \multirow{4}{*}{ A brand } & Constant & & 0.138 & 2.431 & 0.057 & 0.955 \\
\hline & & Difference & & 1 & & & \\
\hline & & AR, Seasonal & Lag 1 & -0.729 & 0.090 & -8.114 & .001 \\
\hline & & Seasonal Diffe & & 1 & & & \\
\hline
\end{tabular}

Table 4- ARIMA model parameters for brand $B$

\begin{tabular}{|c|c|c|c|c|c|c|c|}
\hline Brand & & & & Estimate & $S E$ & $t$ & Sig. \\
\hline \multirow{4}{*}{ B-brand_1 } & \multirow{4}{*}{ B brand } & Constant & & 0.109 & $\begin{array}{l}4.47 \\
4\end{array}$ & 0.024 & 0.981 \\
\hline & & Difference & & 1 & & & \\
\hline & & AR, Seasonal & Lag 1 & -0.321 & $\begin{array}{l}0.13 \\
0\end{array}$ & -2.463 & \\
\hline & & Seasonal diffe & & 1 & & & \\
\hline
\end{tabular}

Table 5- ARIMA model parameters for brand C

\begin{tabular}{lllllll}
\hline Brand & & Estimate & $S E$ & $t$ & Sig. \\
\hline \multirow{2}{*}{ C-brand_1 } & C brand & Constant & -5.020 & 12.260 & -0.409 & 0.684 \\
\cline { 3 - 7 } & & Difference & 1 & & & \\
\cline { 2 - 7 } & & AR, Seasonal Lag 1 & -0.422 & 0.132 & -3.200 & 0.002 \\
\cline { 2 - 7 } & & Seasonal difference & 1 & & &
\end{tabular}

Table 6- ARIMA model parameters for brand D

\begin{tabular}{|c|c|c|c|c|c|c|c|}
\hline Brand & & & & Estimate & $S E$ & $t$ & Sig. \\
\hline \multirow{3}{*}{ D-brand_1 } & \multirow{3}{*}{ D brand } & Constant & & 3.063 & 32.158 & 0.095 & 0.924 \\
\hline & & Difference & & 1 & & & \\
\hline & & AR, Seasonal & Lag 1 & -0.566 & 0.111 & -5.081 & \\
\hline
\end{tabular}

Table 7- ARIMA model parameters for brand $\mathrm{E}$

\begin{tabular}{|c|c|c|c|c|c|c|}
\hline Brand & & & Estimate & $S E$ & $t$ & Sig. \\
\hline \multirow[t]{2}{*}{ E-brand_1 } & E brand & Constant & 156.866 & 13.095 & 11.980 & נF \\
\hline & & Lag 1 & 0.544 & 0.114 & 4.783 & 0.0 \\
\hline
\end{tabular}

The comparison of the estimated tractor sale values for the tractor brands A, B, C, D and E and the actual tractor sale values are given in Figures 10, 11, 12, 13 and 14. When the graphs in the figures are considered, it is seen that the predicted values of the decided model for all tractor brands are in line with the actual values. This shows that the model was successful. 


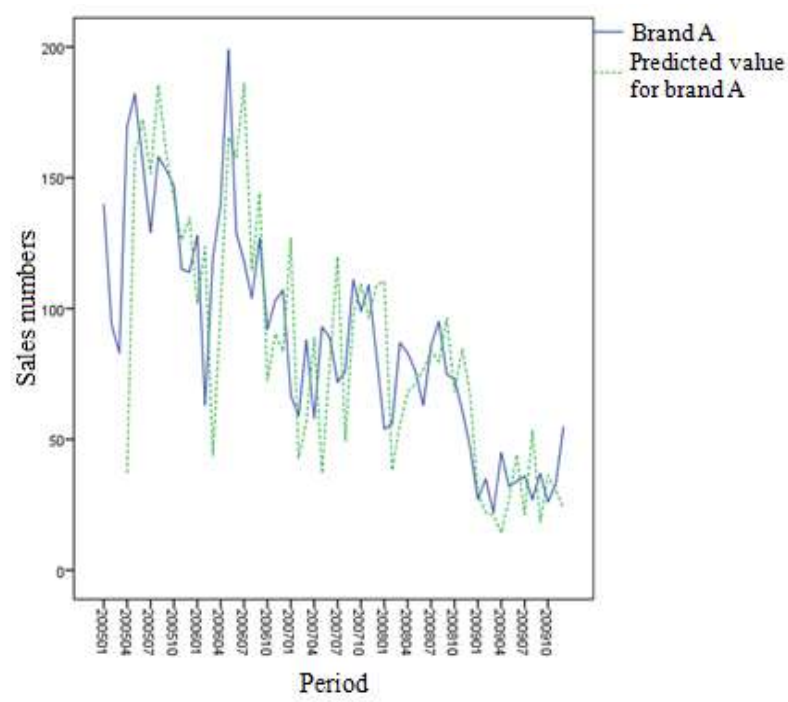

Figure 10- Comparison of actual values with prediction for tractor A brand

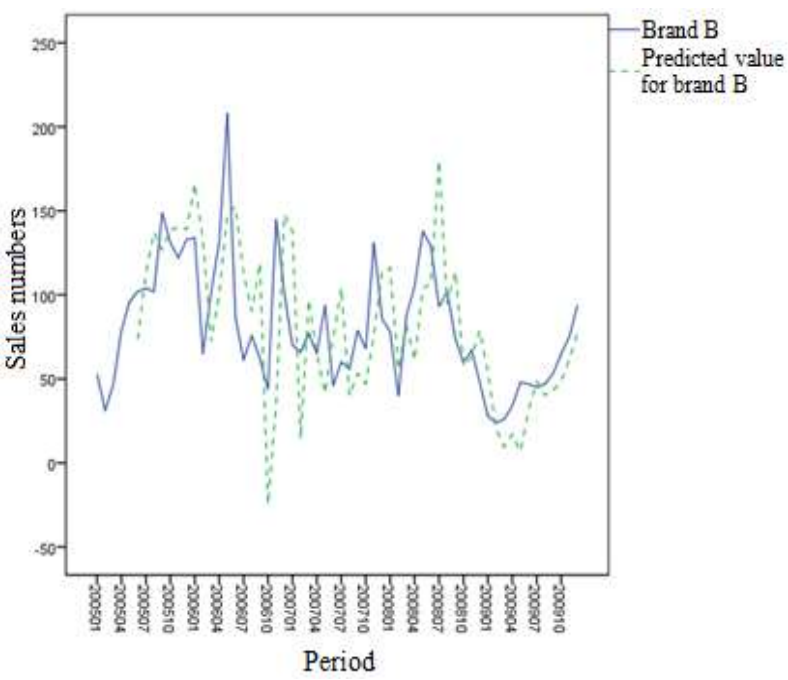

Figure 11- Comparison of actual values with prediction for tractor B brand

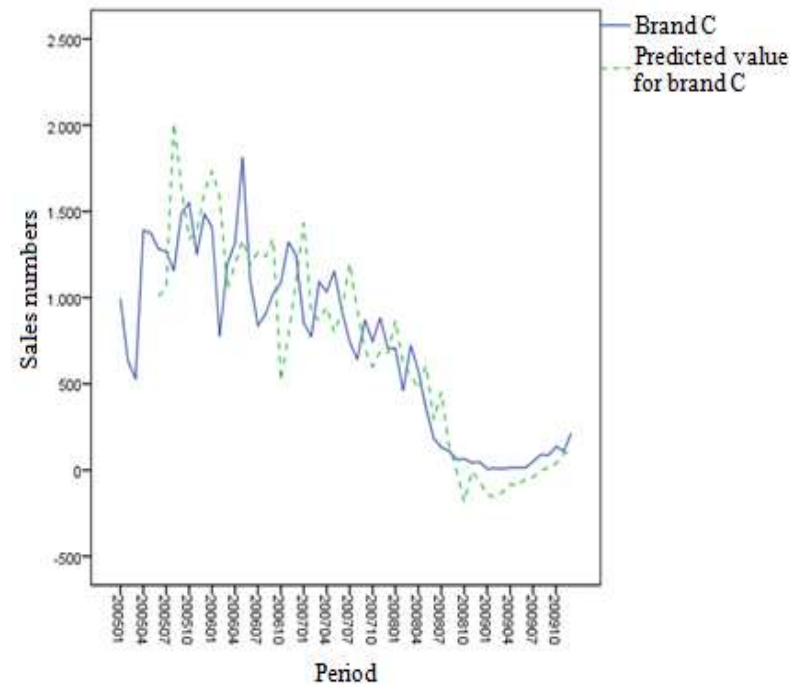

Figure 12- Comparison of actual values with prediction for tractor $\mathrm{C}$ brand 


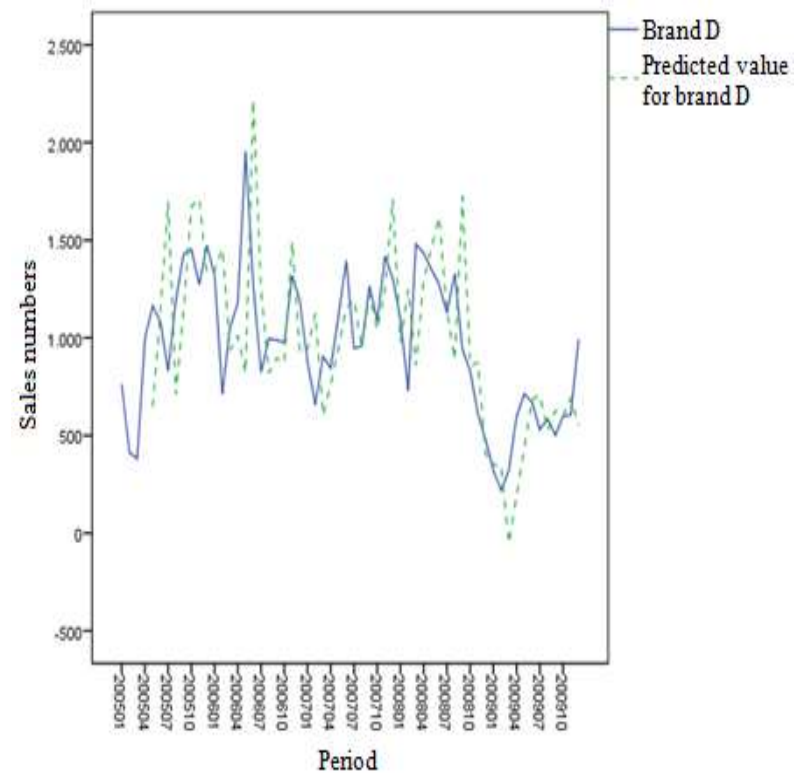

Figure 13- Comparison of actual values with prediction for tractor D brand

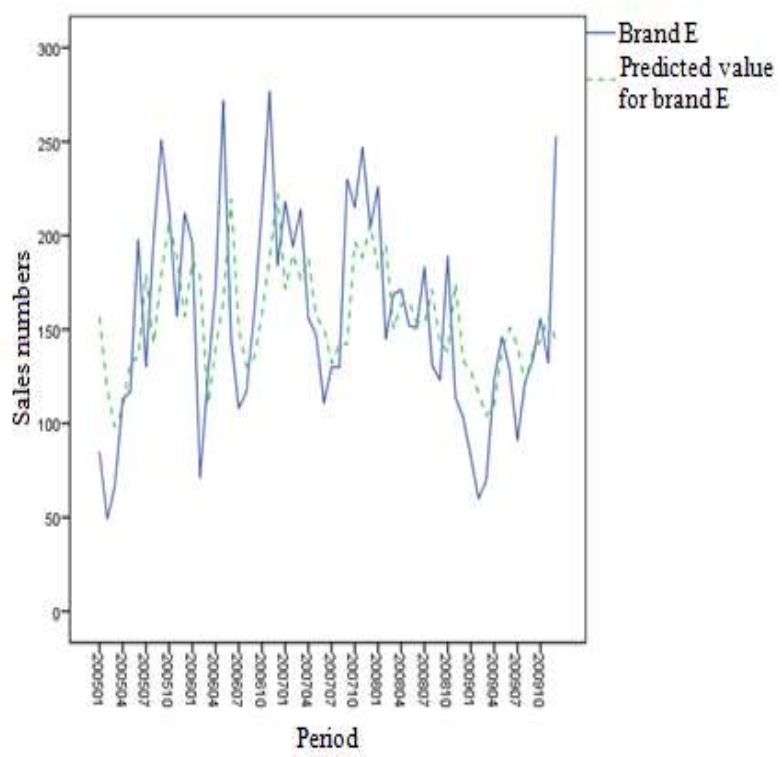

Figure 14- Comparison of actual values with prediction for tractor $\mathbf{E}$ brand

For A, B, C, D and E tractor brands, the actual value of the tractor sales and the estimated lower limits of the tractor sales of these brands and the comparison of the estimated upper limits are examined, it was seen that there was a harmony between the lower limit and upper limit values determined by the model and the actual values. With these results, it is understood that the decided model was successful.

Before going into the estimations, the model's errors should be white noise. To be white noise of the errors indicates that the model's estimates are reliable. The ACF and PACF graphs of the errors should be plotted to see if any errors of the model have occurred. These graphs are obtained from SPSS outputs after the model is decided. For the brands A-BC-D-E the model's errors were determined white noise due to the fact that the majority of the errors are within the limits according to the ACF graph and PACF graphs (Figures 15,16,17,18, and 19). 


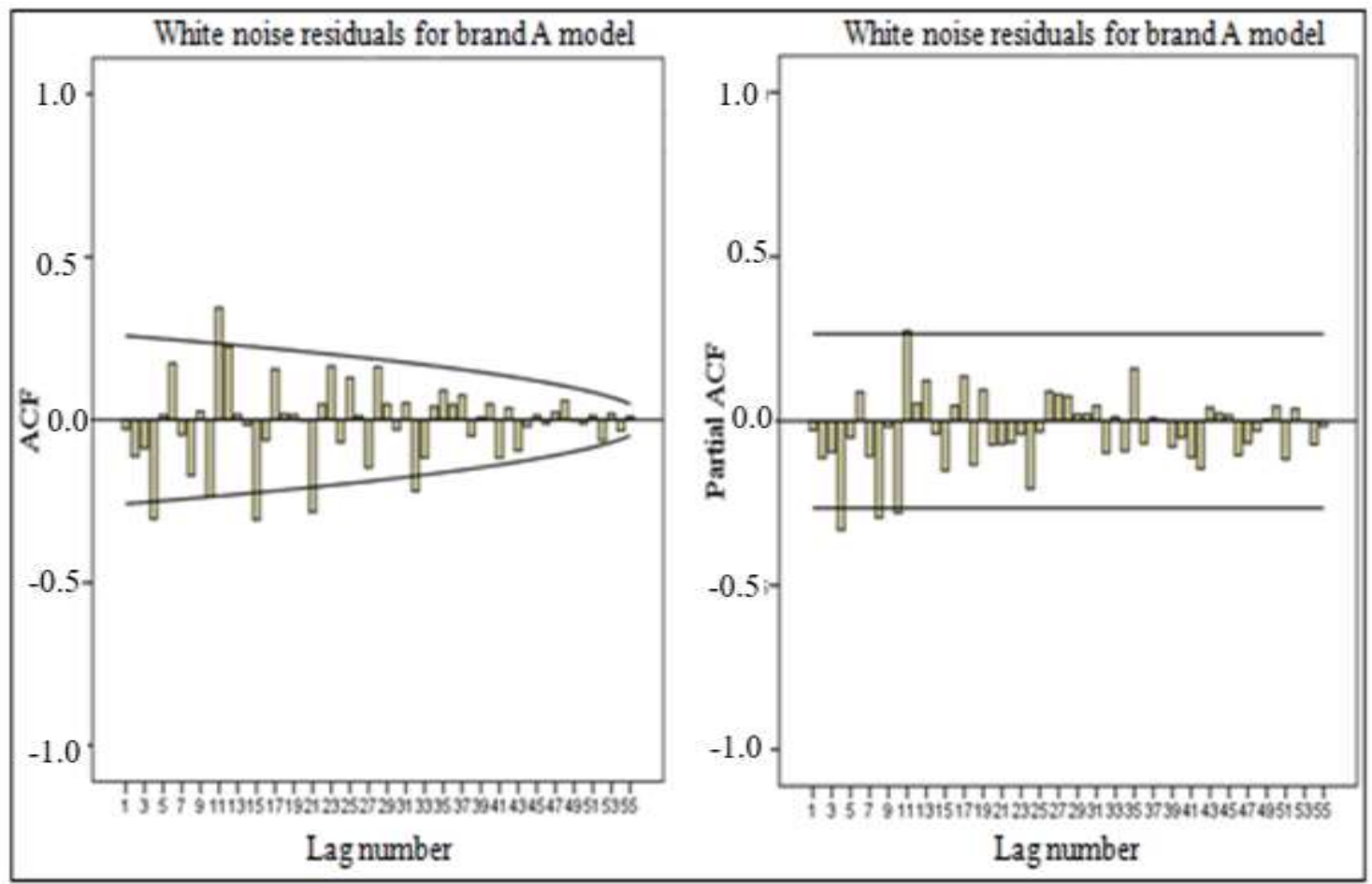

Figure 15- White noise ACF and PACF graph for A brand

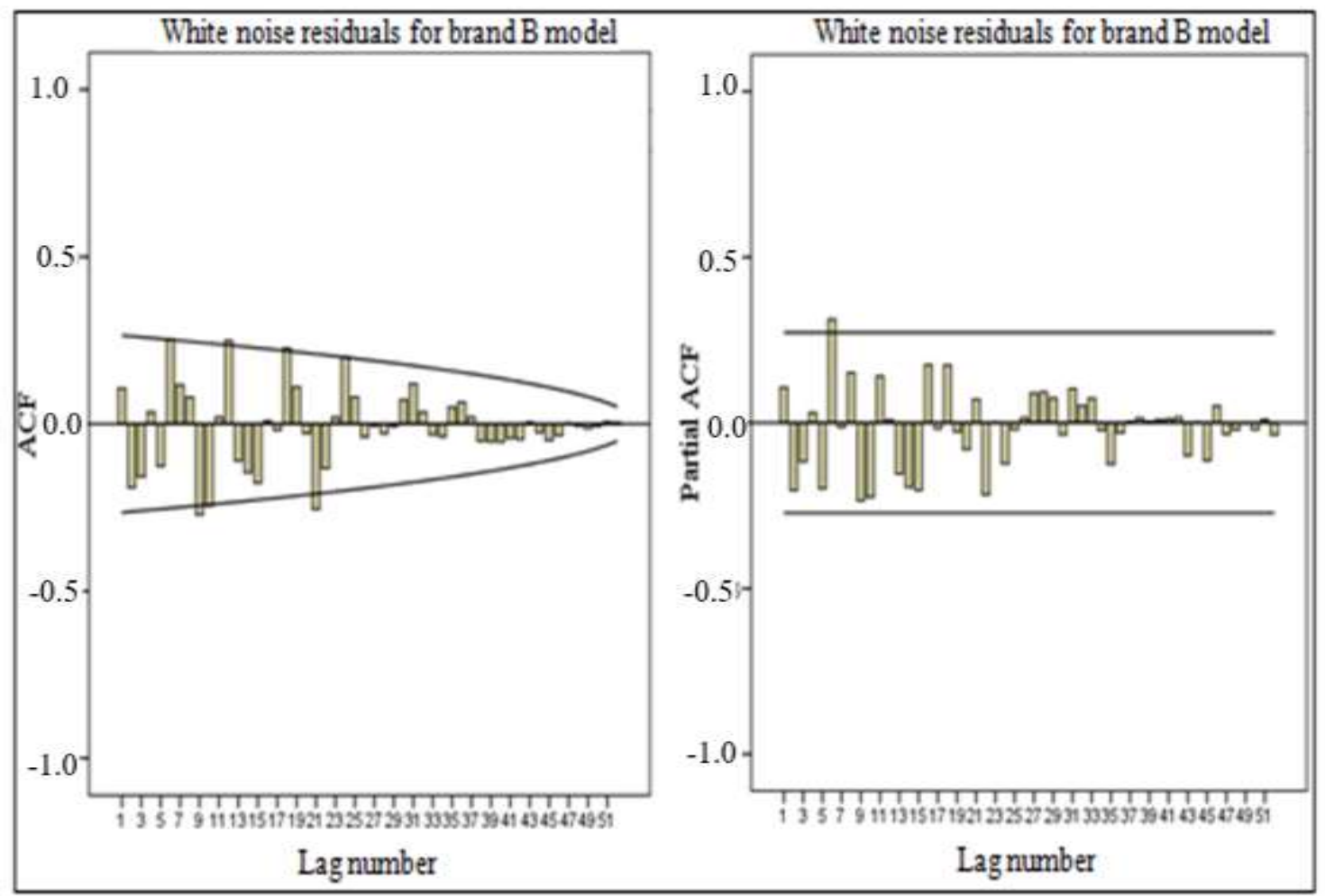

Figure 16- White noise ACF and PACF graph for B brand 


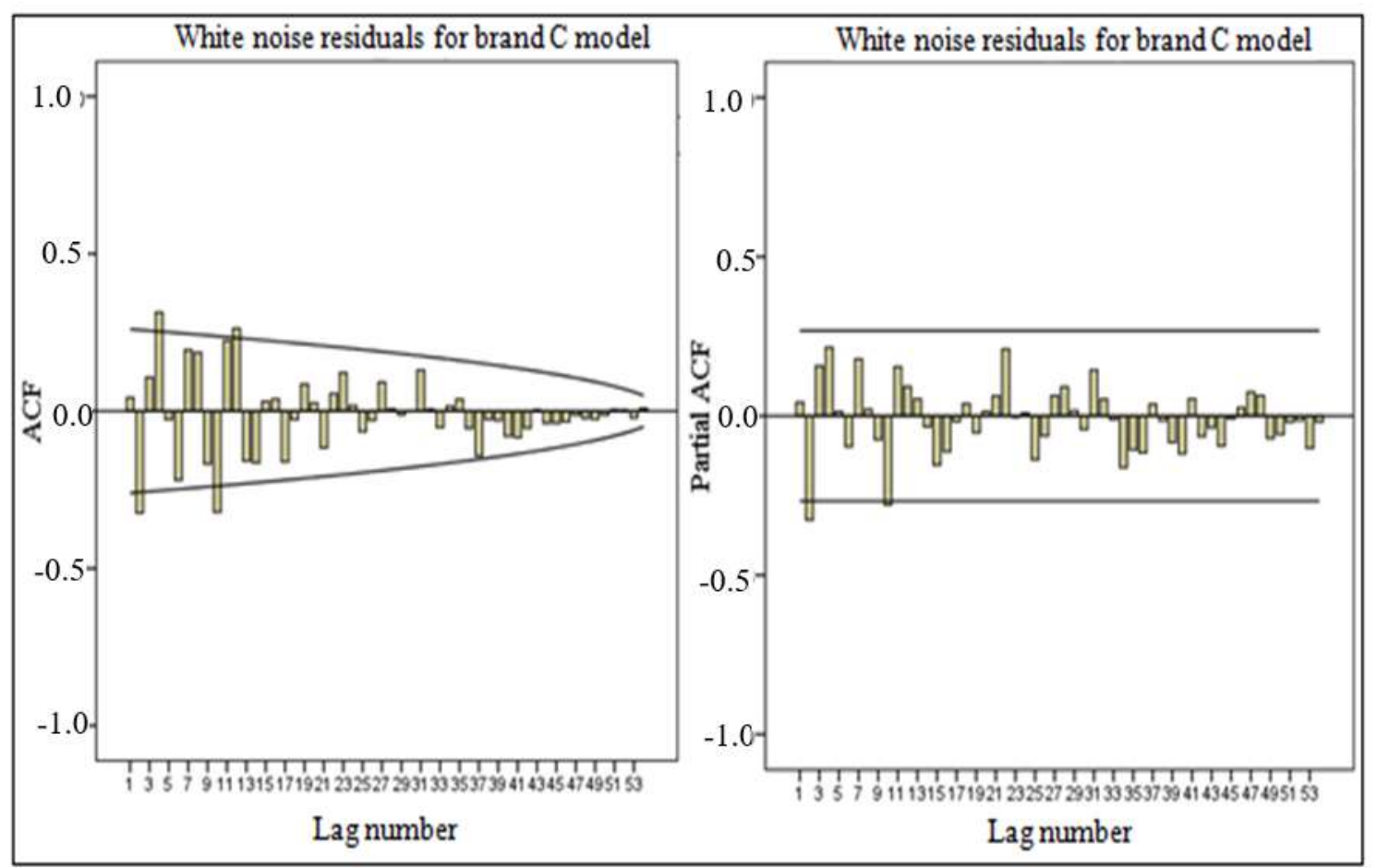

Figure 17- White noise ACF and PACF graph for C brand

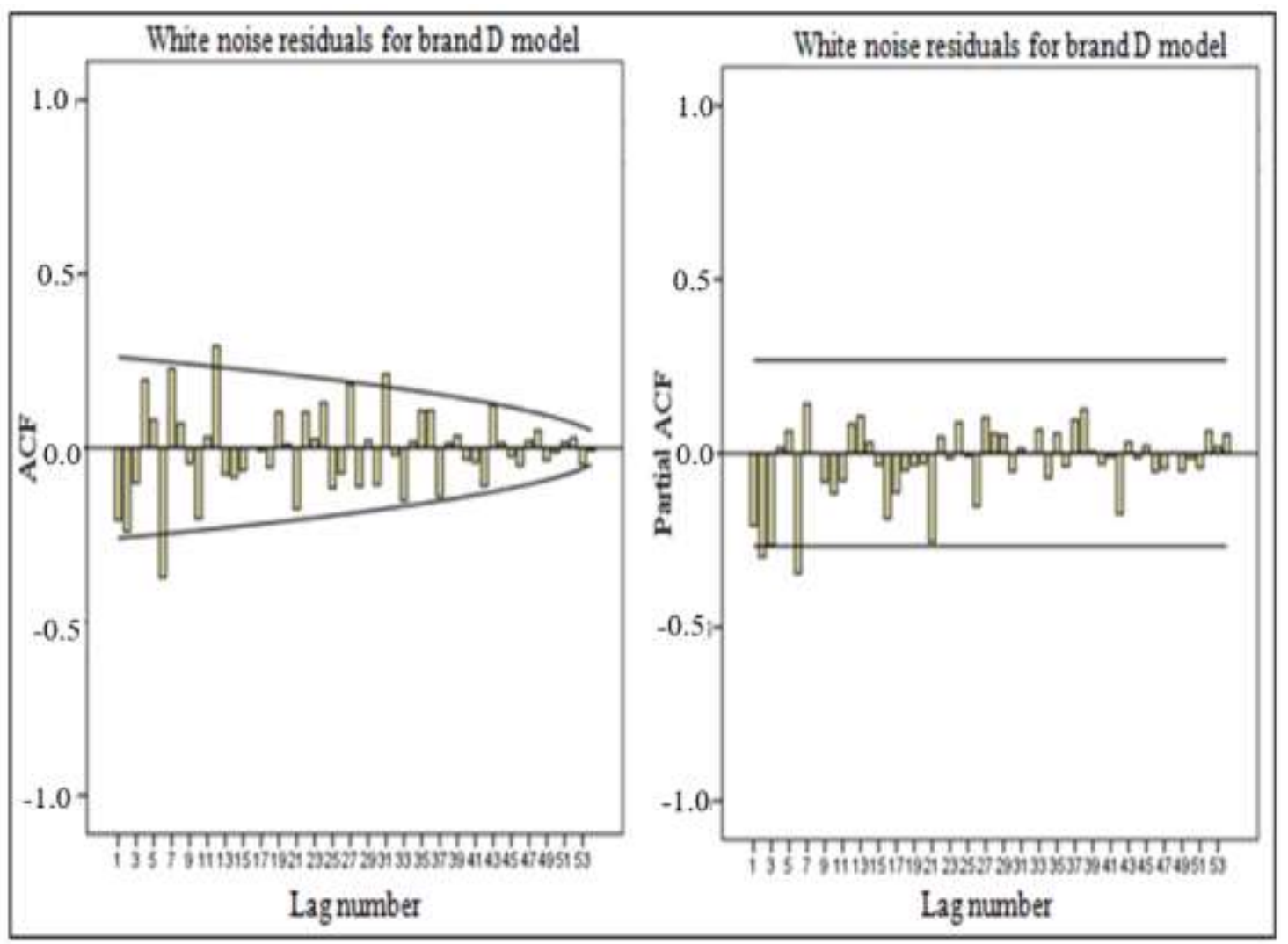

Figure 18- White noise ACF and PACF graph for D brand 


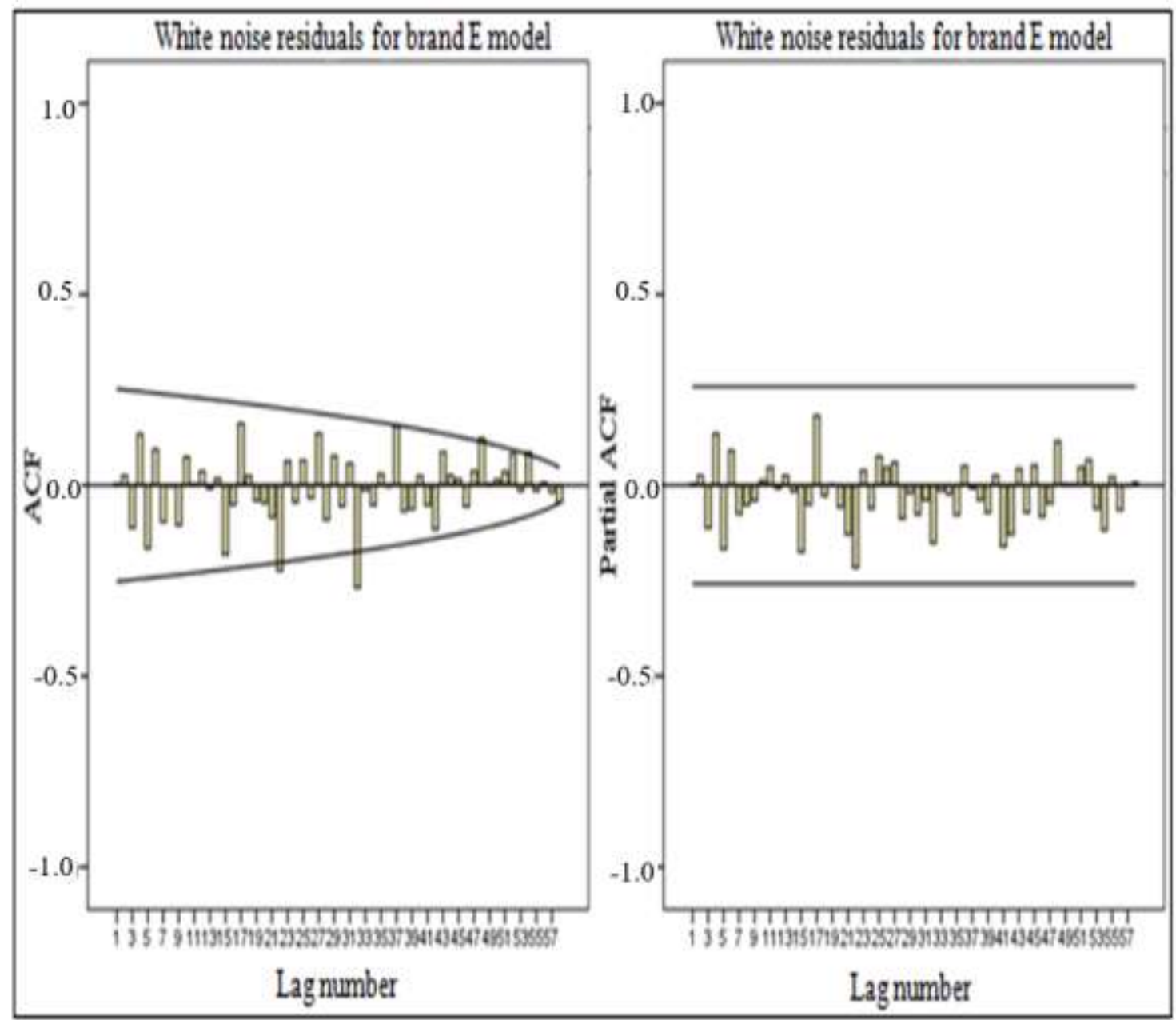

Figure 19- White noise ACF and PACF graph for E brand

After deciding on the most suitable model, the model is entered into SPSS program. Parameter values, error values and estimation values that we want them to be found during model inputs are marked and outputs are obtained in this way. As a result of the outputs obtained, the estimated values for the A, B, C, D and E tractor brands for 2010 are given in Table 8.

Table 8- Estimation values for tractors for 2010

\begin{tabular}{lllllllllllll}
\hline Months & 1 & 2 & 3 & 4 & 5 & 6 & 7 & 8 & 9 & 10 & 11 & 12 \\
\hline Brand A & 64 & 63 & 71 & 86 & 96 & 99 & 107 & 120 & 129 & 135 & 144 & 155 \\
Brand B & 65 & 46 & 61 & 65 & 64 & 41 & 57 & 59 & 62 & 38 & 54 & 56 \\
Brand C & 150 & 173 & 165 & 235 & 189 & 218 & 194 & 271 & 210 & 229 & 205 & 272 \\
Brand D & 961 & 1000 & 1125 & 1171 & 1198 & 1475 & 1481 & 1520 & 1716 & 1750 & 1786 & 2034 \\
Brand E & 209 & 185 & 172 & 165 & 161 & 159 & 158 & 158 & 157 & 157 & 157 & 157 \\
\hline
\end{tabular}

\subsection{Comparison of actual values and estimation values determined by model}

Table 9 shows the average annual sales of five tractor brands for the years 2005-2009. When the table is analyzed, it is seen that the brand D (4831 units) with the highest sales averages between 2005 and 2009 and the brand with the lowest sales average is B (406). Annual average sales values were 445 units in A brand, 3589 units in brand C and 782 units in brand $\mathrm{E}$. The brands A, B and E maintained their sales lines, while the C and D brands reached their maximum sales figures in 2006, and the C brand 2009 and the D brand suffered serious sales losses in 2009. 
Table 9- Annual average sales volume of five tractor brands for 2005-2009 (TUIK 2010)

\begin{tabular}{llllll}
\hline Year & $A$ & $B$ & $C$ & $D$ & $E$ \\
\hline 2005 & 137 & 96 & 1200 & 1037 & 149 \\
2006 & 119 & 101 & 1169 & 1149 & 170 \\
2007 & 84 & 75 & 868 & 1064 & 183 \\
2008 & 71 & 85 & 289 & 1056 & 155 \\
2009 & 34 & 49 & 63 & 555 & 125 \\
Total & 445 & 406 & 3589 & 4861 & 782 \\
\hline
\end{tabular}

Figure 20 shows the graph drawn by taking advantage of the monthly sales figures of 2005-2009 for five tractor brands on a monthly basis. In the graph, it is seen that the brands $\mathrm{C}$ and $\mathrm{D}$, where $\mathrm{A}, \mathrm{B}$, and $\mathrm{E}$ brands maintain their stable structures, have a variable structure on a monthly basis.

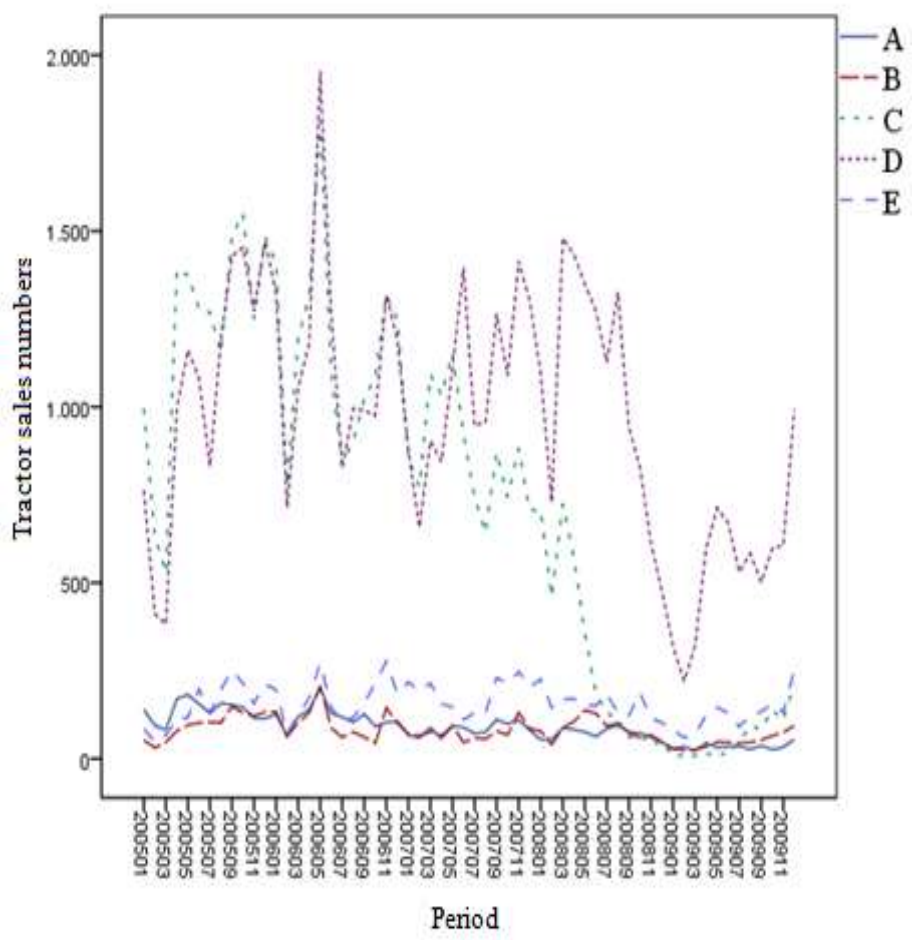

Figure 20- Sales figures distribution of five brands by months

The comparison of the actual sales data of 5 different tractor brands for 2005-2009 years and the estimation values for the same period as determined by the model established by the time series analysis method are given in Table 10. Table 10 shows the $\%$ deviation between the actual values and the estimated values. Percentage deviation values, minimum difference, and maximum difference values were found.

Table 10- Approximate deviation between actual values and estimated values

\begin{tabular}{llllll}
\hline $2005-2009$ & $A$ & $B$ & $C$ & $D$ & $E$ \\
\hline Average of actual values & 89 & 81 & 718 & 972 & 156 \\
Average of difference values & 16 & 19 & 170 & $\% 2$ & 36 \\
\% Deviation & $\% 18$ & $\% 24$ & $\% 24$ & $\% 17$ & 110 \\
Maximum difference & 57 & 62 & 743 & 615 & 1 \\
Minimum difference & 0 & 0 & 4 & 1 & 1 \\
\hline
\end{tabular}

A similar study was conducted for the total number of tractors belonging to the period of 1991-2009. The total number of tractors estimated by time series analysis was obtained and these estimation values were compared with the actual total tractor numbers. The result of the established model; Estimated values were found to be very close to the actual values, 
and according to the difference between the average real and predicted values of the years 1991-2009, the difference between the real and predicted values was found to be $3 \%$. This situation is shown in Table 11.

Table 11- The comparison of the actual values and estimated values of the total number of tractors in the period 1991-2009

\begin{tabular}{llll}
\hline Period (year) & $\begin{array}{l}\text { Actual total } \\
\text { number of tractors } \\
\text { (unit) }\end{array}$ & $\begin{array}{l}\text { Estimated total } \\
\text { number of tractors } \\
\text { (unit) }\end{array}$ & $\begin{array}{l}\text { Difference } \\
\text { values } \\
\text { (unit) }\end{array}$ \\
\hline 1991 & 704373 & 669702 & 34671 \\
1992 & 725933 & 686662 & 39271 \\
1993 & 746283 & 704925 & 41358 \\
1994 & 757505 & 765769 & 8264 \\
1995 & 776863 & 787366 & 10503 \\
1996 & 807303 & 805788 & 1515 \\
1997 & 874995 & 815051 & 59944 \\
1998 & 902513 & 830220 & 72293 \\
1999 & 924471 & 865054 & 59417 \\
2000 & 941835 & 970093 & 28258 \\
2001 & 948416 & 1000804 & 52388 \\
2002 & 970083 & 1013161 & 43078 \\
2003 & 997620 & 987588 & 10032 \\
2004 & 1009065 & 976386 & 32679 \\
2005 & 1022365 & 995126 & 27239 \\
2006 & 1037383 & 1027484 & 9899 \\
2007 & 1056128 & 1041449 & 14679 \\
2008 & 1070746 & 1046317 & 24429 \\
2009 & 1073538 & 1049325 & 24213 \\
Average & 913022 & 896751 & 16271 \\
Deviation $\%$ \%) & 3 & & \\
\hline
\end{tabular}

\section{Conclusions}

Based on our study, the tractor with the highest average sales volume is D brand, followed by the C brand. At the same time, a large amount of change is observed in the sales volumes of these brands. The high amount of change in C and D brands caused the maximum difference between the estimation and the real value to be high. However, the deviations of our estimation values for brands are acceptable. For the period 2005-2009, the\% deviation values obtained between the actual values and the estimated values; it is calculated as $18 \%$ for brand A, $24 \%$ for brand B, $24 \%$ for brand C, $17 \%$ for brand D and $23 \%$ for brand E. In addition, time series analysis Box-Jenkins method was applied in a similar study and the suitability of the method and model was tried to be demonstrated. Estimation values for the same period have been obtained by using the total number of tractors belonging to the period of 1991-2009. In the comparison, it was observed that the estimation values for the period of 1991-2009 were quite close to the real values with a deviation of 3\%. Time series analysis methods can be used as a guide for the decision makers or companies that want to break into many market sectors by providing information on market and sales forecasting. For public institutions or private enterprises, it is very important to make predictions and plan accordingly for the future. This tool can act as guide in certain areas, such as production planning, stock planning and sales planning. Based on this study, it is determined that the estimation method using Box-Jenkins method from time series analysis method can be used to make tractor sales forecasts. This study concludes that tractor companies can use time series method in their future planning to forecast their sales.

\section{References}

Ali B (2015). Time series analysis: A case study on forecasting Turkey's inflation and unemployment. Master Thesis (Unpublished), İstanbul Aydın University, Graduate School of Social Sciences, Department of Business Administration, Istanbul

Alon I \& Sadowsk1 R J (2001). Forecasting aggregate retail sales: A comparison of artificial neural networks and traditional methods. Journal of Retailing and Consumer Services 8(3): 147-156

Bek M İ (2008). Zaman serisi analizi ve tarımsal uygulaması. Yüksek Lisans Tezi (Yayımlanmamış), Kahramanmaraş Sütçü İmam Üniversitesi, Fen Bilimleri Enstitüsü, Zootekni Anabilim Dalı, Kahramanmaraş 
Berberoğlu E (2010). Süt sığırlarında zaman serisi yöntemleriyle laktasyon eğrilerinin modellenmesi. Doktora Tezi (Yayımlanmamış), Ege Üniversitesi, Fen Bilimleri Enstitüsü, Zootekni Anabilim Dalı, İzmir

Burger C J S C, Dohnal M, Kathrada M \& Law R (2001). A practitioners guide to time-series methods for tourism demand forecasting - a case study of Durban, South Africa. Tourism Management 22(4): 403-409

Chu CW \& Zhang G P (2003). A comparative study of linear and nonlinear models for aggregate retail sales forecasting. International Journal of Production Economics 86(3): 217-231

Çelik Ş (2013). Zaman serileri analizi ve trafik kazası verilerine uygulanması. Iğdır Üniversitesi Fen Bilimleri Enstitüsü Dergisi 3(4): 43-51

Kapucuoğlu B (2016). Analitik ağ süreci tekniği ile traktör pazar payı tahmini. Doktora Tezi (Yayımlanmamış), Ankara Üniversitesi Fen Bilimleri Enstitüsü, Tarım Makinaları ve Teknolojileri Mühendisliği Anabilim Dalı, Ankara

Karaman E (2010). Kontrol günü süt verimlerinin zaman serisi yöntemi ile modellenmesi. Yüksek Lisans Tezi (Yayımlanmamış), Akdeniz Üniversitesi, Fen Bilimleri Enstitüsü, Zootekni Anabilim Dalı, Antalya

Oğhan S (2010). Zaman serisi analiz yöntemlerinin karşılaştırılması. Yüksek Lisans Tezi (Yayımlanmamış), Ege Üniversitesi, Fen Bilimleri Enstitüsü, Zootekni Anabilim Dalı, İzmir

Özek T (2010). Zaman serisi modelleri üzerine bir simülasyon çalışması. Yüksek Lisans Tezi (Yayımlanmamış), Selçuk Üniversitesi, Fen Bilimleri Enstitüsü, İstatistik Anabilim Dalı, Konya

Özer O O \& İlkdoğan U (2013). Box-Jenkins modeli yardımıyla dünya pamuk fiyatının tahmini. Tekirdağ Ziraat Fakültesi Dergisi 10(2): $13-20$

Öztaş S (2012). Erzurum ilindeki doğalgaz tüketiminin zaman serileri analizi ile incelenmesi ve bir uygulama. Yüksek Lisans Tezi (Yayımlanmamış), Atatürk Üniversitesi, Fen Bilimleri Enstitüsü, Endüstri Mühendisliği Anabilim Dalı, Erzurum

TUIK 2010.Özel İstatistik, http://www.tuik.gov.tr, Erişim tarihi: 12.05.2012. Ankara

Turgut D \& Temiz İ (2015). Time series analysis and forecasting for air pollution in Ankara: A box-jenkins approach. Alphanumeric Journal 3(2): 131-138

Yeşil A (2007). Stoğa üretim yapan bir işletmede zaman serisi ve yeni nesil talep tahmin yöntemlerinin karşılaştırılması. Yüksek Lisans Tezi, Kocaeli Üniversitesi, Fen Bilimleri Enstitüsü, Endüstri Mühendisliği Anabilim Dalı, Kocaeli

Zhou S L, McMahon T A, Walton A \& Lewis J (2002). Forecasting operational demand for an urban water supply zone. Journal of Hydrology 259(1-4): 189-202 